\title{
ACCIDENT RISK IN PATIENTS WITH EPILEPSY
}

\author{
Karla Teixeira Souza', Marilisa M. Guerreiro², Carlos A.M. Guerreiro ${ }^{3}$
}

\begin{abstract}
Objective: To compare the risk of accidents in patients with uncontrolled seizures, in seizure-free patients, and in patients with chronic headache. Method: This was a prospective longitudinal case-controlled study with interviews. A semi-structured questionnaire was used in the epilepsy and headache outpatient clinics of the Hospital das Clinicas of UNICAMP. Results: Group I was composed of 48 patients with uncontrolled seizures, group II was composed of 24 seizure-free patients and group III was composed of 32 patients with headache. Thirty-nine patients (81\%) in group I, 13 (54\%) in group II, and 19 (59\%) in group III reported accidents in the last two years. In the first group, 649 accidents (89\%) were related to epileptic seizures and the average number of accidents not related to seizures was 1.7. The average number of accidents in groups II and III were both 2.4. Conclusion: Epileptic seizure was the most important factor determining the occurrence of accidents in people with epilepsy.
\end{abstract}

KEY WORDS: seizure, accidents, seizure-related injury, epilepsy.

\section{Risco de acidentes em pacientes com epilepsia}

Resumo - Objetivo: Comparar o risco de acidentes em pacientes com crises epilépticas não-controladas, em pacientes com crises epilépticas controladas e em pacientes com cefaléia crônica. Método: Estudo prospectivo longitudinal caso-controle realizado por meio de entrevistas com pacientes dos ambulatórios de epilepsia e cefaléia crônica do HC-UNICAMP. Resultados: $O$ grupo I foi composto por 48 pacientes com crises nãocontroladas, o grupo II foi composto por 24 pacientes com crises controladas e o grupo III foi composto por 32 pacientes com cefaléia crônica. Trinta e nove pacientes (81\%) do grupo I, 13 (54\%) do grupo II e 19 (59\%) do grupo III relataram acidentes nos últimos dois anos. No primeiro grupo, 649 acidentes (89\%) foram relacionados a crises epilépticas. A média do número de acidentes não relacionados a crises por pessoa de cada grupo foi 1,7 para o grupo I e 2,4 para os dois outros grupos. Conclusão: As crises epilépticas foram o principal fator de risco para a ocorrência de acidentes em pacientes com epilepsia.

PALAVRAS-CHAVE: crise epiléptica, epilepsia, acidentes, lesões induzidas por crises epilépticas.

Epilepsy is a neurological disorder characterized by repeated unprovoked seizures in the absence of a toxicmetabolic or febrile condition. Epileptic seizures are due to abnormal excessive transitory electrical discharges by nerve cells'. Patients with epilepsy have an increased risk of accidents and injuries when compared to the general population ${ }^{2-4}$. Some authors agree that the majority of people with epilepsy suffer accidents related to seizures ${ }^{5,6}$. Other studies suggest that the number of accidents not related to seizures in epileptic patients is lower than in non-epileptic individuals ${ }^{7,8}$. Trauma, burns, cuts, and fractures are among the most frequent injuries. The most common site of injury in patients with epilepsy is the head ${ }^{5,9,10}$. Another frequent type of accident is burns sustained from hot water during cooking or bathing ${ }^{11-13}$. For this reason, some authors recommend the use of a microwave oven, which is considered safer than the traditional oven. However, recent studies have showed that even microwave ovens present some risk for patients with complex partial seizures ${ }^{14}$.

The risk of fracture has been associated with one or more tonic clonic seizures per year. Another aspect of fracture risk is the prolonged use of antiepileptic drugs $(A E D s)^{15}$, for different hypothetical reasons. One possible reason is the central nervous system action of AEDs that may cause somnolence or dizziness, which might facilitate the occurrence of fall and consequently fractures, independently of seizures ${ }^{16}$. A second possibility is the potential reduction in the bone mineral density, osteomalacia and osteoporosis, which can lead to increased risk of fracture, particularly in the elderly ${ }^{5}$.

Departament of Neurology, Medical Sciences School, Campinas State University, Campinas SP, Brazil (UNICAMP): ${ }^{M e d i c a l ~ S t u d e n t ; ~}{ }^{2}$ Professor of Child Neurology; ${ }^{3}$ Professor of Neurology. Karla Teixeira Souza received a scholarship from SAE/UNICAMP.

Received 17 December 2007. Accepted 1 March 2008.

Dr. Carlos A.M. Guerreiro - Departamento de Neurologia / FCM / Unicamp - Caixa Postal 6111 - 13083-970 Campinas SP - Brasil. E-mail: guerreiro@ fcm.unicamp.br 
The objective of the current study is to correlate the occurrence and the presence of epileptic seizures and the risk of accidents in epileptic patients compared with patients without epileptic seizures.

\section{METHOD}

This prospective study was done in the Epilepsy and Headache Outpatient Clinics of our University Hospital (HC-UNICAMP), between April/2006 and June/2007. All participants signed the informed consent, approved by the Ethics Committee of our Medical School.

Group I included epileptic patients with uncontrolled seizures and group II included patients with epilepsy who had been seizure-free for at least two years. Group III included patients with chronic headache (control group).

Inclusion criteria were age 18 or older and diagnosis of epilepsy (groups I and II) and chronic headache (group III) for the last two years. We excluded patients with severe mental retardation or patients with neurological examination abnormalities, such as motor deficit or ataxia.

Epilepsy syndromes were classified according to the International League Against Epilepsy Commission Report ${ }^{17}$.

Patients were interviewed using a semi-structured questionnaire about diagnosis and duration of epilepsy and headache; use of medication and doses; the occurrence and type of injury (fall, burn, fracture, abrasion, wound, drowning); number of injuries in the last two years; car accident; and medical assistance needed for the accidents.

A comparative analysis of the results of the patients with epilepsy, seizure-free or not, and the headache group was performed. We used either a chi-square or a Fisher exact test to compare ratios. For a two-group comparison with continuous or discrete measurement, the Mann-Whitney test was used, and among the three groups, the Kruskal-Wallis test was used. The significant statistical level considered was 0.05 .

\section{RESULTS}

We studied 104 patients: 67 women and 37 men. Age varied from 20 to 70 years, with an average of 44 years.

In group I, there were 48 patients with uncontrolled epilepsy. Age of first seizure varied from one month to 44 years, and the average was 14.9 years. Seizure frequency varied from once a year to 14 seizures a day, with a median of two seizures per month. Epilepsy syndromes were symptomatic (or probably symptomatic) focal epilepsies (30 patients), idiopathic generalized epilepsies (4), epileptic encephalopathies (2), and undefined epilepsy syndrome (12).

Group II consisted of 24 seizure-free patients. The age of the first seizure varied from two to 53 years, and the average was 12.7 years. The seizure-free period varied from two to 10 years, with an average of 4.8 years. Epilepsy syndromes were symptomatic (or probably symptomatic) focal epilepsies (11 patients), idiopathic generalized epilepsies (6), and undefined epilepsy syndrome (7).

The control group (group III) included 32 patients with chronic headache. Their ages varied from three to 44 years, and the average was 15 years. Clinical diagnoses were migraine without aura (10), cervicogenic headache (8) migraine with aura (6), tension headache (2), trigeminal-autonomic headache (2), basilar migraine (1), posttrau-

Table 1. Comparison of accident events between patients with uncontrolled epilepsy (group I) and seizure-free patients (group II + group III).

\begin{tabular}{lcccc}
\hline Variable & Group I $(\mathrm{n}=48)$ & Group II $(\mathrm{n}=24)$ & Group III $(\mathrm{n}=32)$ & Statistical analysis \\
\hline Occurrence of accidents & 39 & 13 & 19 & $\mathrm{p}=0.0286$ (Chi-square) \\
Occurrence of falls & 32 & 6 & 13 & $\mathrm{p}=0.0416$ (Chi-square) \\
Occurrence of burns & 12 & 4 & 8 & $\mathrm{p}=0.6706$ (Chi-square) \\
Occurrence of fractures & 7 & 4 & 1 & $\mathrm{p}=0.2008$ (Fischer) \\
Occurrence of contusion-cut & 16 & 5 & 6 & $\mathrm{p}=0.7846$ (Chi-square) \\
\hline
\end{tabular}

Table 2. Number of falls and burns per group.

\begin{tabular}{|c|c|c|c|}
\hline $\begin{array}{l}\text { Variable } \\
\text { ( } \mathrm{n}=\text { number of patients) }\end{array}$ & $\begin{array}{l}\text { Group I } \\
(n=48)\end{array}$ & $\begin{array}{l}\text { Group II } \\
(n=24)\end{array}$ & $\begin{array}{c}\text { Group III } \\
(n=32)\end{array}$ \\
\hline Occurrence of falls & $650(n=19)$ & $29(n=6)$ & $39(n=13)$ \\
\hline $\begin{array}{l}\text { Occurrence of falls requiring } \\
\text { medical assistance }\end{array}$ & 32 & 3 & 3 \\
\hline Occurrence of burns & $37(n=5)$ & $15(n=4)$ & $22(n=8)$ \\
\hline $\begin{array}{l}\text { Occurrence of burns requiring } \\
\text { medical assistance }\end{array}$ & 12 & 1 & 0 \\
\hline
\end{tabular}


Table 3. Comparison between the average number of accidents within the three groups evaluated according to Kruskal-Wallis* test.

\begin{tabular}{lcccc}
\hline & Variable & $\mathrm{N}$ & Average & $\mathrm{p}$-value* \\
\hline Group I & Falls & 32 & 20.3 & 0.0069 \\
& Burns & 12 & 3.1 & 0.1968 \\
\multirow{5}{*}{ Group II } & CCW & 16 & 1.4 & 0.6534 \\
& Falls & 6 & 4.8 & \\
& Burns & 4 & 3.8 & \\
Group III & CCW & 5 & 1.8 & \\
& Falls & 13 & 3.0 & \\
& Burns & 8 & 2.8 & \\
\hline & CCW & 6 & 1.7 & \\
\hline
\end{tabular}

$\mathrm{N}$, number of patients; $\mathrm{CCW}$, contusion-cut wounds.

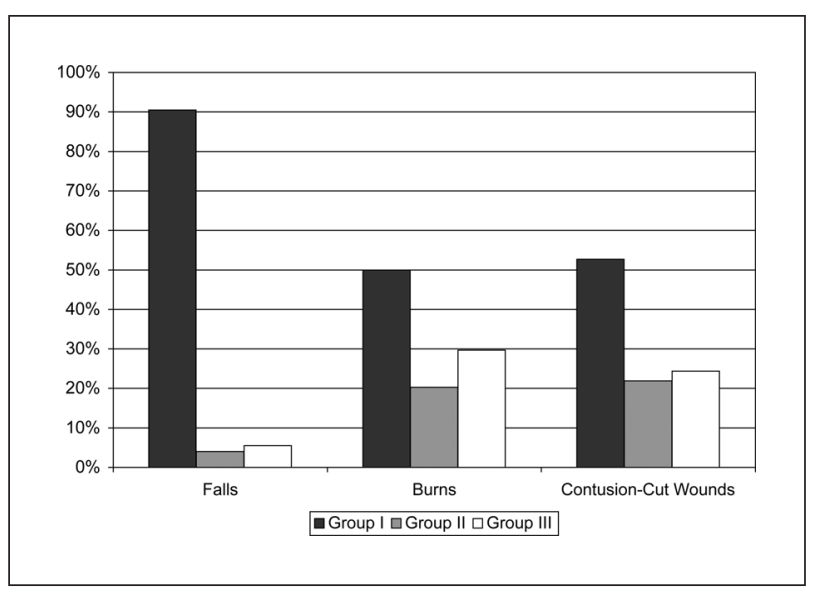

Figure. Types of accidents per group.

matic headache (1), benign intracranial hypertension after ventricular shunt procedure (1), and post-coitus headache (1). Twenty-six patients (81\%) were on prophylactic medication.

Accidents during the last two years were more frequent in patients with uncontrolled seizures $(p<0.05$; Table 1), being present in 39 patients (81\%) of group I, 13 patients (54\%) of group II, and 19 patients (59\%) of group III. The amount and accident type are detailed in the Figure. Falls were significantly more frequent in group I patients $(p<0.05$; Table 2).

Among the 732 accidents found in group I, 649 (88\%) accidents were due to seizures, happening during or immediately after the event. Eighty-three accidents were not related to seizures. These data gives an average of 1.7 accidents not seizure related in group $\mathrm{I}$.

There were 58 accidents in group II, and 78 accidents in group III, giving an average of 2.4 accidents not related to seizure in each of these groups.

Burn injuries were found in $25 \%$ of uncontrolled seizure patients ( $n=37$ events) (Table 3). However medical as- sistance was necessary in 12 cases, with five (10.4\%) being considered serious enough for the patient to be admitted to a hospital.

There was no report of motor vehicle accidents among the three groups.

\section{DISCUSSION}

Our results suggest that patients with uncontrolled seizures are at greater risk of accidents. The use of AEDs and epilepsy syndromes were similar in both groups of patients with epilepsy history. The occurrence of epileptic seizure in the first group was the main risk factor for having an accident. This is in keeping with other studies that found higher risk of accidental injuries in persons with epilepsy, predominantly due to seizures ${ }^{5,6}$.

The average number of accidents not related to seizure was the same in the epileptic patients who were seizure free as those who were not, and the headache patients. Similar results have been found in the literature ${ }^{7}$ and can be explained by the caution patients with epilepsy apply in regular activities.

The occurrence and number of falls were significantly greater in patients with epileptic seizures when compared to the other two groups. A fall was the most frequent type of accident for the three groups, representing $82 \%$ of all described injuries, followed by burns and abrasion-cut lesions. Thirty-two patients with seizures (group I) had falls and some required medical assistance. In the same group, 37 burn events were observed and 12 needed medical care. These data are greater than previously described ${ }^{12,13}$. One possible explanation for this finding is related to the low socioeconomic level of our population. In our country, epileptic women are still responsible for the housework, including cooking and ironing. This is an important point to be addressed when one considers prevention and recommendation for daily activities, especially when the epileptic seizures are not completely controlled. Besides higher educational level, developed societies seem to offer greater exposure to protection measures.

Burns, which were a frequent finding in our study, rarely occur in children with epilepsy. A recent study did not mention burns among seizure related accidents in epileptic children while contusion, skin laceration, head trauma, broken tooth and bone fracture were listed ${ }^{18}$.

The low socioeconomic level of our patients precludes the majority of them to drive. This justifies our finding of no occurrence of car accident among our patients. Nevertheless, the risk of motor vehicle accidents in drivers with epilepsy appears to be increased ${ }^{5,8}$.

We should endeavor to focus our attention on identifying the group of epileptic patients at higher risk of 
accidents, particularly those who, despite medical treatment, persist with epileptic seizures. This group should be encouraged to adopt protection measures.

ACKNOWLEDGEMENTS - The authors thank the staff and residents who assisted the patients at the Epilepsy and Headache Outpatient Clinics - HC/UNICAMP and the Statistical Section - FCM.

\section{REFERENCES}

1. Guerreiro CAM, Guerreiro MM. Noções gerais. In: Guerreiro CAM, Guerreiro MM (Eds). Epilepsia: o paciente otimamente controlado. São Paulo: Lemos Editorial, 1999:7-16.

2. Cornaggia CM, Beghi M, Moltrasio L, Beghi E; RESt-1 Group. Accidents at work among people with epilepsy: results of a European prospective cohort study. Seizure 2006;15:313-319.

3. Tomsom T, Beghi E, Sundqvist A, Johannessen SI. Medical risk in epilepsy: a review with focus on physical injuries, mortality, traffic accidents and their prevention. Epilepsy Res 2004;60:1-16.

4. Ficker DM. Sudden unexplained death and injury in epilepsy. Epilepsia 2000;41(Suppl 2):S7-S12.

5. Wirrel EC. Epilepsy-related injuries. Epilepsia 2006;47(Suppl 1):S79-S86.

6. Broek M van der, Beghi E. Accidents in patients with epilepsy: types, circumstances and complications: a European cohort study. Epilepsia 2004;45:667-672.

7. Neufeld MY, Chistik V, Kogan E, Korczyn AD. Physically traumatic events in patients with epilepsy compared with non-epileptic subjects. Seizure 2000;9:595-597.

8. Cornaggia CM, Beghi M, Moltrasio L, Beghi E; RESt-1 Group. Morbidity and accidents in patients with epilepsy: results of a European cohort study. Epilepsia 2002;43:1076-1083.

9. Kirby S, Sadler RM. Injury and death as a result of seizures. Epilepsia 1995;36:25-28.

10. Neufeld MY, Chistik V, Kogan E, Korczyn AD. Life-long history of injuries related to seizures. Epilepsy Res 1999;34:123-127.

11. Unglaub F, Woodruff S, Demir E, Pallua N. Patients with epilepsy: a high-risk population prone to severe burns as a consequence of seizures while showering. J Burn Care Rehabil 2005;26:526-528.

12. Kinton L, Duncan JS. Frequency, causes and consequences of burns in patients with epilepsy. J Neurol Neurosurg Psychiatry 1998;65:404-405.

13. Spitz MC. Injuries and death as a consequence of seizures in people with epilepsy. Epilepsia 1998;39:904-907.

14. Toledo JC, Lowe MR. Microwave oven injuries in patients with complex partial seizures. Epilepsy Behav 2004;5:772-774.

15. Souverein PC, Webb DJ, Weil JG, Van Staa TP, Egberts AC. Use of antiepileptic drugs and risk of fractures: case-control study among patients with epilepsy. Neurology 2006;66:1318-1324.

16. Persson HBI, Alberts KA, Farahmand BY, Tomsom T. Risk of extremity fractures in adult outpatients with epilepsy. Epilepsia 2002;43:768-772.

17. Engel J Jr. ILAE Commission Report. A proposed diagnostic scheme for people with epileptic seizures and with epilepsy: report of the ILAE task force on classification and terminology. Epilepsia 2001;42:796-803.

18. Buffo TH, Guerreiro MM, Tai P, Montenegro MA. Seizure related accidents and injuries in childhood. Arq Neuropsiquiatr 2008;66 (in press). 